\title{
On the Construction of Professional Culture of International Trade Practice in Higher Vocational Colleges
}

\author{
Yang Zhang, Yao Xiong \\ Jiangxi Biotech Vocational College, Nanchang, 330220, China
}

Keywords: practice of International Trade; higher vocational colleges; professional culture

\begin{abstract}
With the development of society and economy as well as the advancement of modernization, the cultivation of modern talents is no longer limited to the imparting of knowledge, but pays more attention to the influence of professional skills and culture. Professional culture is an indispensable part of modern campus culture. Good professional culture can help students to establish correct professional values, and cultivate good moral and professional spirits, and plays a great role in the higher level of employment and development of students. Therefore, in higher vocational colleges, the construction of professional culture is particularly important in the process of professional practice and training of talents.
\end{abstract}

\section{Introduction}

As an inexhaustible force on the spiritual level, culture can help people to understand and change the world, transform their thinking concepts, as well as recognize activities and social practices. The development culture plays an important role in promoting economic construction, developing educational undertakings and training new talents.

\section{Construction of Professional Culture}

Professional culture refers to the sum of all the spirits and material wealth which accord with the professional characteristics and the spirit of times and are condensed in the long-term professional development process. The core of professional culture is the assimilation of professional values and moral behaviors of teachers and students. After the professional culture is formed, it will exert a subtle influence on everyone which will transform professional thoughts into conscious behaviors.

\subsection{Cultural Construction}

\subsubsection{General plan}

In order to learn from the modern enterprise culture and cultivate new application talents, to build a professional culture that meets the needs of the society, conforms to the professional law with the professional abilities and characteristics of times has become an urgent need for the professional development of higher vocational colleges. As the saying goes, Rome is not build in one day, so the construction of professional culture can not be accomplished overnight. In the opposite, it needs accurate professional orientation, clear development goal and perfect facilities to carry on the overall planning. Talents training is a systematic project which is not only the acquisition of knowledge, the training of vocational skills, but also the soaking and edifying of vocational culture. Professional culture is an important part in the construction of campus culture. It is a relevant cultural dynamic system with professional scientific theory as its core, in which professional ideological contents, spiritual features, methods and techniques overlap with each other, owning features such as diversity, variety and professionalism which plays an imperceptible and fundamental role in students' professional study and is able to guide them to set up good professional values, professional ethics and professional spirits. The construction of professional culture plays an indispensable role in the process of cultivating high-quality skilled talents. 


\subsubsection{Construction thoughts}

The construction of professional culture needs to be guided by the core values of the specialty. It is necessary to adjust the operation of colleges' organization, to form the professional values of the faculty and students, to perfect the rules and regulations of colleges, to build the practical training bases on campus and to cultivate talents for cooperation between colleges and enterprises. To realize this, we need to integrate resources in many aspects, integrate and develop it comprehensively in an all-round way in long-term efforts, and strive for an accumulate quantity.

\subsection{Professional Culture of International Trade Practice}

International Trade Practice is to train senior technical and application talents who master the basic theories with strong practical abilities, and engage in import and export business as well as management. Practical training includes Foreign Trade Correspondence, Market Research and Prediction, Foreign Trade Negotiation Skills, Simulation Training, as well as the main special curriculum and practice steps. With the continuous development of economic globalization, constantly strengthened degree of global economic integration, and the continuous development of multinational companies, the past domestic trade can no longer fully meet the needs of people's lives. International trade has existed in ancient times. From the Opium War to the Reform and Opening up, international trade, even in wartime, never completely stopped. In today's world, with the enhancement of trade and the rise of electronic commerce, the development of international trade has been pushed into a new historical trend. Modern society is in an urgent need of a large number of professional talents. In response to this, the cultivation of application talents is the original intention of higher vocational colleges, and the construction of professional culture is particularly important.

\section{Practice of Professional Culture Construction of International Trade}

International trade is a kind of foreign business activity with complicated trading environment, sophisticated transaction procedure, the terms and conditions of the transaction which are different from the domestic trade, as well as greater risk than the domestic trade. These characteristics require that the talents trained by relevant majors in vocational colleges should not only master the basic contents, knowledge, skills and methods of International Trade, but also possess a certain pioneering spirit and professional quality.

\subsection{Contents of Professional Culture of International Trade}

The main contents of professional culture construction include professional spiritual culture, professional material culture, professional system, professional humanistic culture and so on. Professional spiritual culture is an important embodiment of professional culture. The construction of professional spiritual culture includes professional idea, training goal, training specification and so on. The major of International Trade Practice aims to develop a good professional ethics, team work spirits, strong communication skills, professional ability of international trade, foreign language application ability and computer operation skills. Besides, students should also be able to develop the international market skillfully, organize business negotiations, sign import and export contracts, foreign trade contracts, and prepare documents and other practical operations. They must be high-end skilled personnel and "emphasis good faith, are good at foreign trade, have strong skills, own high quality".

\subsection{Construction of Professional Culture of Higher Vocational Colleges}

Theoretical courses of International Trade Practice include Western Economics, International Trade, International Trade Practice, International Finance, International and Commercial Law. However, the courses offered by the major of International Trade Practice in higher vocational colleges are mostly practical and applied subjects in the study of import and export trade in goods. The characteristics of the subject of International Trade decide that major teaching should emphasis on the cultivation of students' practical application abilities based on the main points of basic theory 
knowledge and cannot simply rely on teachers to impart knowledge according to material contents. In view of the characteristics of higher vocational colleges, whether colleges can cultivate graduates who meet the requirements of the market becomes an important index to measure the quality of their professional development. Many higher vocational colleges attach great importance to this aspect. They have spent a great deal of financial, material and manpower resources on training bases, double quality teachers, teaching reform, etc. However, as an excellent and mature higher vocational college, in addition to continuous improvement in the above aspects, they must also have an excellent and mature professional culture. This requires higher vocational colleges to draw lessons from and introduce the excellent enterprise culture construction experience of modern society in professional teaching and talent training, and to explore the way of professional culture construction in accordance with the spirit of the present era by combining with the actual concrete conditions of higher vocational colleges.

\section{Practice of Professional Culture Construction of International Trade}

Many higher vocational colleges in China have set up majors related to international trade, which recruit a large number of excellent students every year, and colleges have also made active exploration and attempt in the construction of professional culture.

\subsection{Existing Problems}

\subsubsection{Equate professional culture with campus culture}

Professional culture includes the value orientation of teachers and students, the code of conduct and so on. It is a part of campus culture, but this dose not mean that it equals to campus culture. Some colleges and universities devolve the task of building professional culture to organizations, such as student associations, league committees, and so on. They often play a role in the students' ideological and political aspects within the cultural construction, and is of little help for them to embark on the social road in the future.

\subsubsection{Construction of professional culture does not correspond to occupation}

The difference between higher vocational education and undergraduate education lies in their professional orientation, and their professional setting is mainly determined by occupation or post. The core competitive ability of graduates in higher vocational colleges exists in their professional characteristics in the process of training, which means that they can enter their posts as soon as they leave. Therefore, in the construction of professional culture in higher vocational colleges, more professional elements should be reflected, and the characteristics of vocational education should be more obvious.

\subsection{Practical Suggestions}

\subsubsection{Adequate construction planning}

In all aspects of colleges' daily work, the professional values of International Trade can be fully permeated, and its ultimate goal is to cultivate students' excellent thinking mode and behavior habits. For the major of International Trade, professional researchers and teachers are required to maintain close contact with first-line enterprises, interact with enterprises, develop school-based textbooks for the cooperation between schools and enterprises and teach students the case of economics and trade and excellent corporate culture.

\subsubsection{Organize a powerful teaching team}

In order to achieve a good teaching effect, there must be a good team. In the daily teaching of various specialties, colleges should strengthen teachers' vocational skills and teaching abilities, introduce the corresponding reward system and incentive mechanism, organize professional teachers to work in the cooperative enterprises in a planned way, make them contact with employees of the enterprises intimately, and make them experience modern enterprise culture 
personally. Colleges are also suggested to regularly invite relevant experts and entrepreneurs to give lectures in order to broaden teachers' horizons. Thus, professional teachers can better teach students and help them enter a higher level.

\subsection{Professional Culture should be Permeated in Daily Teaching}

For example, the course of College Students Career Planning have been set up in many colleges. The courses are opened in general in the second to third grade, but many students are busy doing the writing of graduation thesis or job seeking, so they have no time to think about their career planning. Therefore, I suggest that this course be adjusted to set up for freshmen. Relevant teachers should also have a basic understanding of the major before teaching, or choose some teachers with foreign trade enterprise background to teach when the college organizes practical training. When teaching, they should combine professional situations to guide students to make career plannings. In addition, these teachers can also visit outside training base, invite entrepreneurs and outstanding graduates into the classroom, watch films and other forms. Thus, as soon as the freshmen enter colleges, they will have a basic understanding of the positions they may be engaged in the future, and will have a relatively pragmatic plan for their own career, and at the same time, to a certain extent, they can avoid a blind major transition.

\subsection{Cooperation between Colleges and Enterprises during the Construction of Professional Culture}

The goal of talents training in higher vocational education is to train high quality skilled professionals. The core competitiveness of these students is not only reflected in the theoretical level, but also in the degree of docking with enterprises. The course study of International Trade Practice requires students to pay attention to practice and application, and to their comprehensive application ability. Therefore, in the process of cultivating talents in this major, we should pay more attention to the cooperation between colleges and enterprises. From the point of view of colleges and universities, cooperation is conducive to better serving the local economy and grasping the direction of professional cultural construction. From the point of view of enterprises, it is conducive to recruiting employees who meet the requirements of the post and are able to take up posts directly. From the point of view of students, it is helpful to know the enterprise culture and professional culture through the cooperation platform between colleges and enterprises, and to understand the industries and enterprises during the study period, which will benefit the future career selection and job hunting. In addition, understanding the corporate culture, management experience, social responsibility and other aspects of excellent enterprises will stimulate students' initiatives and awareness of professional learning. For the practical major of International Trade in higher vocational colleges, the cooperation is often reflected in the form of establishing a training base together by colleges and enterprises. For example, the training room is designed according to the real working scenes of foreign trade companies, and the introduction of enterprises and outstanding graduates are posted which are helpful to create a harmonious campus atmosphere with professional cultural construction. Besides, some colleges and universities have also introduced foreign trade companies directly into the campus, arranged students to observe the specific business, and set up a bridge between students and front-line business personnel outside the classroom.

\subsection{Excellent Corporate Culture needs to be Referred and Absorbed}

The standard of recruiting employees in modern enterprises requires not only certain professional skills, but also professional accomplishments, such as devotion to work, teamwork, honesty, innovation and so on. Therefore, in addition to creating a professional culture that integrates into the industry and enterprise elements in the environment, colleges should properly use excellent corporate culture to subtly guide and influence students in their daily education and management. For examples, foreign trade managers can be invited to enter the classroom to communicate with students about the requirements of employees in terms of competence and qualities, to introduce corporate culture, and to look forward to the future of industry. In addition, the excellent graduates of this major can be introduced to students indirectly to cultivate their 
professional literacy and vocational skills.

\subsection{Fusion of Campus Activities with Professional Culture Construction}

Various campus activities are effective ways to improve students' literacy. Campus activities, such as community activities, are characterized by strong cohesion, rich contents, flexibility, self-discipline, wide influence, and so on, which are some of the most accessible forms of education for students. Campus activities can not only enrich students' extracurricular cultural life, but also can improve their comprehensive qualities and promote the construction of campus culture and majors. Modern psychology holds that only in a relaxed, equal and free environment can personality and talents be brought into full play. Therefore, independent and flexible campus activities play an important role in expanding students' comprehensive qualities and cultivating innovative spirits and practical abilities. Various forms of campus activities have become an important carrier of campus culture construction and professional culture construction.

\section{Outlook and Development}

Professional construction is one of the most important capital construction in higher vocational colleges. It is the key to cultivate high-quality application talents and is the basis of serving local economic construction. It determines the quality and level of talents training. The construction of professional culture is also the only way for colleges to enhance their abilities and comprehensive strength!

\section{References}

[1] Shao Qingxiang. On the Practical Innovation of Professional Culture Construction in Higher Vocational Colleges [J]. Party Construction and Ideological Education in Colleges, 2011.

[2] Ma Yingshuang, Li Ping. Research on Practical Teaching Reform of Marketing Management Course in Vocational Colleges [J]. Brand (Theory Version), 2011. 